УДК : 316.334:37 + 314.93-057.8

\title{
ОСВІТА, ОСВІТНІ ОРІЕНТАЦІЇ ТА ПРОФЕСІЙНА ПІДГОТОВКА МОЛОДІ УКРАЇНИ НА ФОНІ ЄВРОІНТЕГРАЦІЇ: СТАТИСТИЧНІ ТА СОЦІОЛОГІЧНІ ВИМІРИ
}

\section{Сірий Євген Володимирович}

доктор соціологічних наук, професор,

ДУ «Державний інститут сімейної та молодіжної політики», м. Київ, Україна

ORCID: 0000-0003-3396-8168

socio1@ukr.net

Даний матеріал висвітлює одну із ключових проблем взаємодії освіти та ринку праці - поточний розвиток освітніх орієнтації та професійної підготовки молоді в контексті сучасних тенденцій розвитку молодіжного сегменту ринку праці в Україні у розрізі статистичних та окремих соціологічних замірів цієї сфери. Метою дослідження $\epsilon$ статистичний опис багатьох різноманітних сторін цього процесу, що відображає максимально наближену реальну картину поточного стану та розвитку цієї освітньої сфери. На основі наявних статистичних даних, показників емпіричних соціологічних досліджень 3 цієї проблематики, були описані такі їі сторони, як: загальні ситуаційні аспекти та їх тенденції; кількісна динаміка розвитку інститутів освіти та суб'єктів освітньої діяльності, доступ та охоплення освітою, її привабливість та мотиваційні аспекти, професійні вподобання, задоволеність молоді освітою та перспективи працевлаштування, інтереси та плани молоді на побудову кар'єри, проблеми професійної освіти, освітня міграція. Було дано часткову оцінку особливостям розвитку професійної освіти в контексті основних проблем. На підставі даного статистико-соціологічного опису був доповнений висновок щодо ситуації у сфері професійної освіти в Україні, основним проблемним чинником якої $\epsilon$ низький рівень темпів суспільно-економічного розвитку України, який суттєво впливає на процес взаємопроникливості життєвих цілей, професійних перспектив молодої людини, з одного боку, та трансформуючої освітньо-професійної системи, з іншого.

Ключові слова: професійна освіта; ринок зайнятості; статистичні та соціологічні показники. 
Siryy Evgen, Doctor of Social Sciences, Professor, State Institution "State Institute of Family and Youth Policy", Kyiv, Ukraine

Education, Educational Orientations and Vocational Training of Ukrainian Young People against the Background of European Integration:

\section{Statistical and Sociological Dimensions}

The article highlights one of the key problems of the interaction between education and the labour market - the current development of educational orientation and vocational training of young people in the context of nowadays trends in the development of the youth segment of the labour market in Ukraine. The issue is highlighted in the context of statistical and individual sociological measures in this area. The purpose of the study is to provide a statistical description of many different aspects of this process, reflecting the closest possible real picture of the current state and development of this educational field. On the basis of available statistics, empirical sociological studies on this issue, its sides were described as: general situational aspects and their tendencies; quantitative dynamics of development of educational institutions and subjects of educational activity; access to and coverage of education, its attractiveness and motivational aspects; professional preferences, youth satisfaction with education and employment prospects; interests and plans of young people for career development; problems of vocational education, educational migration. There was given a particular assessment of the features of the vocational education development in the context of the main problems. Based on this statistical and sociological description, there was drawn a conclusion on the situation in the field of vocational education in Ukraine, with the main problem of which being the low level of socio-economic development of Ukraine, which significantly influences the process of interpenetration of life goals, professional prospects of young people, on the one hand, and a transformative educational and professional system, on the other.

Key words: vocational education; employment market; statistical and sociological indicators.

Сирый Евгений Владимирович, доктор социологических. наук, профессор, Государственный институт семейной и молодежной политики, 2.Киев, Украина

Образование, образовательные ориентации и профессиональная подготовка молодежи Украины на фоне евроинтеграции: статистические и социологические измерения

Данный материал освещает одну из ключевых проблем взаимодействия образования и рынка труда - текущее развитие образовательных ориентаций и профессиональной подготовки молодежи в контексте современных тенденций развития молодежного сегмента рынка труда в Украине, в разрезе 
статистических и отдельных социологических замеров этой сферы. Целью исследования является статистическое описание множества различных сторон этого процесса, что отражает максимально приближенную реальную картину текущего состояния и развития этой образовательной сферы. На основании имеющихся статистических данных, данных эмпирических социологических исследований по этой проблематике, были описаны такие ее стороны, как: общие ситуационные аспекты и их тенденции; количественная динамика развития институтов образования и субъектов образовательной деятельности, доступ и охват образованием, ее привлекательность и мотивационные аспекты, профессиональные предпочтения, удовлетворенность молодежи образованием и перспективы трудоустройства, интересы и планы молодежи на построение карьеры, проблемы профессионального образования, образовательная миграция. Было дано частичную оценку особенностям развития профессионального образования в контексте основных проблем. На основании данного статистико-социологического описания был дополнен вывод о ситуации в сфере профессионального образования в Украине, основным проблемным фактором которой является низкий уровень темпов общественно-экономического развития Украины, который существенно влияет на процесс взаимоприемливости жизненных целей, профессиональных перспектив молодого поколения, с одной стороны, трансформируя образовательно-профессиональной системы, с другой.

Ключевые слова: профессиональное образование; рынок занятости; статистические и социологические показатели.

\section{Вступ}

Нішу молодіжної зайнятості визначають однією 3 пріоритетних складових соціальної політики. Однак, однією із ключових проблем їі вирішення є регулювання ринку освітніх послуг в аспекті трансформації системи професійної освіти, на тлі європейської інтеграції України. Вирішення цього питання потребує системного дослідницького аудиту, моніторингу щодо різних змін, трендів у процесі розвитку професійної освіти та професійної підготовки молоді в Україні. Дана проблематика потребує системного аналізу з врахуванням як зовнішніх, так i внутрішніх латентних чинників, що впливають на самоорганізацію та синхронність у взаємодії ринку праці та ринку освітніх послуг у самореалізації молодого покоління.

\section{Аналіз останніх досліджень і публікацій}

В аналізі питань процесу розвитку професійної підготовки молоді є здобутки і результати наукових досліджень багатьох вітчизняних вчених, зокрема: Т. Боттаєвої, Л. Колєшні, І. Кравченко, Е.Лібанової, О. Мартякової, Н. Ничкало, С. Оксамитної, І. Петрової, В. Радкевича, Є. Савельєва, В. Савченка, 
М. Семикіної, С. Ткачук, Д. Шестаковської та ін. Однак, відчутність браку знань з боку комплексних емпіричних соціологічних досліджень 3 аналізованої проблематики, у доповненні соціально-статистичних показників розвитку системи професійної освіти, не дозволяє системно проаналізувати дану проблематику. На основі цього можна дати ціліснішу характеристику цій проблематиці і з'ясувати суть найбільш виражених проблем.

\section{Формулювання мети і завдань статті}

Актуальність та мета дослідження визначається необхідністю системного вивчення особливостей розвитку сучасної освіти, освітніх орієнтацій та професійної підготовка молоді у статистичних та соціологічних вимірах для постійної уніфікації програми регулювання, як молодіжної політики, так і трансформації освітньо-професійної сфери. Дослідження має описовий характер. Хоч означена проблематика та система опису іï i має елементи традиційної усталеності, однак в межах систематизації матеріалу щодо сучасних тенденцій професійної підготовки молоді, автором було зібрано оновлену інформація, на підставі якої робився опис та аналіз сучасного стану розвитку професійно-освітньої сфери за останні кілька років.

\section{Виклад основного матеріалу дослідження}

Освіта, будучи органічною частиною життя суспільства, відображає рівень його розвитку, суперечності, проблеми. I для ефективного виконання своїх соціальних функцій необхідне їі оновлення з урахуванням актуальних світових тенденцій їі розвитку, національних потреб, самореалізації та творчого розвитку особистості. За останнє десятиліття в Україні відбулися істотні трансформації, пов'язані з функціонуванням професійно-освітньої системи, яка стала одним із сегментів ринкових відносин. Значно змінилися характер і масштаби попиту на фахівців різних напрямів професійної підготовки та адаптації молодих людей до реалій інформаційного суспільства. Тісна взаємодія ринку праці та ринку освітніх послуг залишається важливим фактором змін і появи нових тенденцій як в освітньому просторі, так і у формуванні людського капіталу, в суспільно-економічному розвитку країни. I сьогодні в Україні гостро стоять проблеми, пов'язані з недосконалістю механізмів взаємодії освіти та ринку праці.

Не дивлячись на потужний потенціал системи надання освітніх послуг населенню та процес реформування, професійна освіта не спроможна вирішити ключову проблему - привести підготовку кваліфікованих робітників у відповідність до потреб ринку праці. Розрив між попитом і пропозицією робочої сили є очевидним. Крім того, викликає занепокоєння факт підвищеного попиту на працівників найпростіших професій, що спричинює спрямованість роботодавців на дешеву робочу силу, що не сприяє інноваційному розвитку. Аналіз показує, що системно, причину даної ситуації складають, різнорівневі 
чинники. Це i: слабка соціальна захищеність молоді, іiі неготовність до конкурентного існування; стереотипність уявлень значної частини молоді про престиж професій внаслідок розмаху тіньової економіки, патерналістська культура та психологія, низька інституційна ефективність державної політики. Важливою тенденцією професійної освіти $є$ і підприємницькі цінності, орієнтація на економічну діяльність. Ринкова економіка ставить якісно нові завдання у вихованні та освіті молоді. Однак, за відносно короткий період не слід чекати швидких змін у традиційно усталеному українському соціуму, щодо формувань нового відповідного етосу в нових соціально-економічних реаліях.

Аналізуючи процеси в освітній сфері, можна зазначити, що Україна не стоїть осторонь загальносвітових тенденцій, а формує власну освітню політику на тлі світових змін з впровадженням нових європейських стандартів. Сьогодні здійснюється глибинна трансформація сфери професійної освіти. Протягом 2017-2018н. р. МОН України активно долучалось до нормативноправового забезпечення ії діяльності. Діяльність закладів освіти України регулюється нормативними документами, серед яких Закон України «Про освіту» (2017), Закон України «Про загальну середню освіту» (2017), Закону України «Про професійну (професійно-технічну) освіту» (2019), Національна стратегія розвитку освіти в Україні на період до 2021 р. (2017), Пріоритетні напрями реформування профільної шкільної освіти окреслено також у Концепції Нової української школи (2016). Важливим механізмом успішного оновлення освітньої системи $\epsilon$ перехід до компетентнісної парадигми профільної освіти через впровадження Національної рамки кваліфікацій (2011), призначеної задля налагодження ефективної взаємодії сфери освітніх послуг та ринку праці. Започатковані заходи щодо удосконалення державної системи професійної орієнтації населення в Україні.

У рамках Програми Державної служби зайнятості щодо професійної орієнтації населення на 2017-2020 рр., запроваджено профорієнтаційне супроводження учнів закладів загальної середньої освіти. У сфері середньої освіти функціонують програмно-методичні комплекси забезпечення професійного самовизначення учнів старшої школи в умовах профільного навчання, на кшталт: «Побудова кар'єри», «Моя майбутня професія...» та ін. Для забезпечення якісної підготовки кадрів утворено Національне агентство кваліфікацій, підготовлено Концепцію підготовки фахівців за дуальною формою здобуття освіти (2018р.). Однак ефективність цих заходів є майже не помітною.

Важливим напрямом освітніх змін є трансформація сфери професійної (професійно-технічної) освіти та вищої освіти у розрізі структури освітньої системи. Згідно даних Державної служби статистики, за останні 4 роки 
Міжнародні відносини: теоретико-практичні аспекти

Випуск 5 (2020)

ISSN (print) 2616-745X; ISSN (online) 2616-7794

кількість закладів вищої освіти всіх рівнів акредитації (з 2015-16 р. по 2018-19 р.) практично залишалася незмінним: несуттєве зменшення на 7 од. (див. Табл. 1/Рис. 1). Однак кількість закладів професійної (професійнотехнічної) освіти зменшилась на 8\% (- 62 од.).

\begin{tabular}{|l|c|c|c|c|}
\hline \multicolumn{2}{|c|}{ Таблиця 1} \\
\hline $\begin{array}{l}\text { Кількість 3ВО I ІІ рівн. акр.(коледжі, } \\
\text { технікуми, училища) }\end{array}$ & 371 & 370 & 372 & 370 \\
\hline $\begin{array}{l}\text { Кількість 3В0 III- IV рівн. акр. } \\
\text { (університети, академії, інститути) }\end{array}$ & 288 & 287 & 289 & 282 \\
\hline $\begin{array}{l}\text { Кількість закладів професійної } \\
\text { (професійно-технічної) освіти }\end{array}$ & 798 & 787 & 756 & 736 \\
\hline
\end{tabular}

Джерело: складено автором за матеріалами (Derzhavna sluzhba statystyky: zaklady vyshchoi osvity, 2005; Osvitnia reforma: rezultaty ta perspektyvy: informatsiino-analitychnyi zbirnyk, 2019)

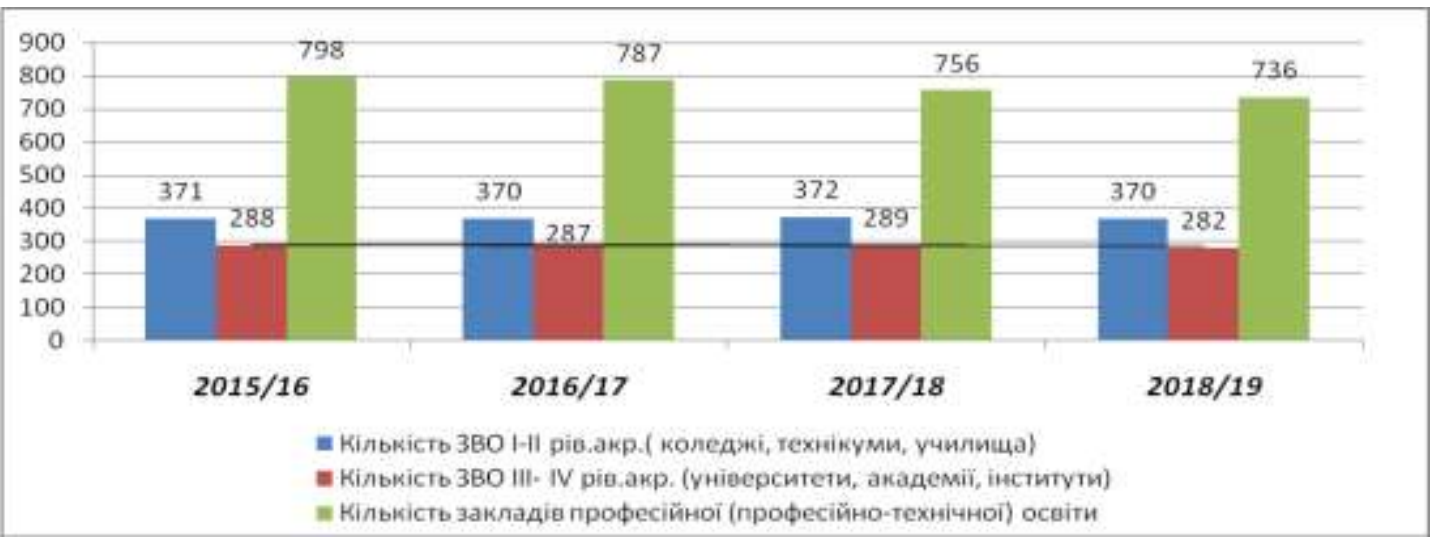

Рис. 1. Динаміка змін професійно-освітніх закладів

Освітня структура молоді за останні 4-5 років $\epsilon$ також умовно стабільною. Однак, упродовж 2014/2015-2018/2019 н.pp. спостерігається приблизно пропорційна тенденція до зменшення кількості здобувачів освіти за всіма рівнями, окрім повної загальної середньої освіти (див. Табл. 2/Рис. 2). Зміни відбувались у зменшенні кількості слухачів та студентів середніх професійних та вищих навчальних закладів.

Протягом останніх років внаслідок погіршення демографічної ситуації (старіння населення, зниження народжуваності), збільшення частки молоді, зорієнтованої на здобуття вищої освіти, відбувалося поступове зменшення контингенту учнів, слухачів закладів професійної (професійно-технічної) освіти (ПТ0). Загальний контингент учнів, слухачів закладів ПТО скоротився за останні 4 роки майже на $16 \%$ (49,1 тис. осіб). Загальна кількість слухачів 
закладів вищої освіти I-II рівн. акр.(коледжі, технікуми, училища) скоротився майже на $13 \%$ (-30,2 тис), контингент студентів закладів вищої освіти III-IV рівн. акр. (університети, академії, інститути) за цей же період зменшився на $4 \%$ (-53 тис.). Це $\epsilon$ наслідком як демографічного спаду (за останні 3 роки, з 2016 р. по 2018 р. кількість молоді у віковій групі 15-19 років зменшилася приблизно на 47 тис. осіб), так і активізації процесу робочої та освітньої міграції, падіння престижу робітничих професій серед молоді. Окремим чинником виступає i недосконалість системи професійної орієнтації i кар'єрного консультування молоді.

Однак, питома вага «університетської» молоді серед всіх студентів та слухачів у продовж останніх 4 років, за даними Державної служби статистики, залишилася практично не змінною (+2\%). Це свідчить про збереження престижності вищої освіти серед населення та поширення популярності вищої освіти серед молоді.

Таблиця 2

\begin{tabular}{|c|c|c|c|c|}
\hline & $2015 / 16$ & $2016 / 17$ & $2017 / 18$ & $2018 / 19$ \\
\hline $\begin{array}{l}\text { Кількість осіб у ЗВО I-II рівн. акр (коледжі, } \\
\text { технікуми, училища), тис. }\end{array}$ & 230,1 & 217,3 & 208,6 & 199,9 \\
\hline $\begin{array}{l}\text { Кількість осіб у } 3 \text { ВО } \text { III-IV piвн. акр. } \\
\text { (університети, академії, інститути), тис. }\end{array}$ & 1375,3 & 1369,4 & 1330 & 1322,3 \\
\hline $\begin{array}{lcr}\text { Загальний } & \text { контингент } & \text { учнів, слухачів } \\
\text { закладів } & \text { професійної } \\
\text { технічної) освіти, тис. } & \text { (професійно- }\end{array}$ & 304,1 & 285,8 & 269,4 & 255 \\
\hline
\end{tabular}

Джерело: складено автором за матеріалами: (Derzhavna sluzhba statystyky: zaklady vyshchoi osvity; Osvitnia reforma: rezultaty ta perspektyvy: informatsiino-analitychnyi zbirnyk)

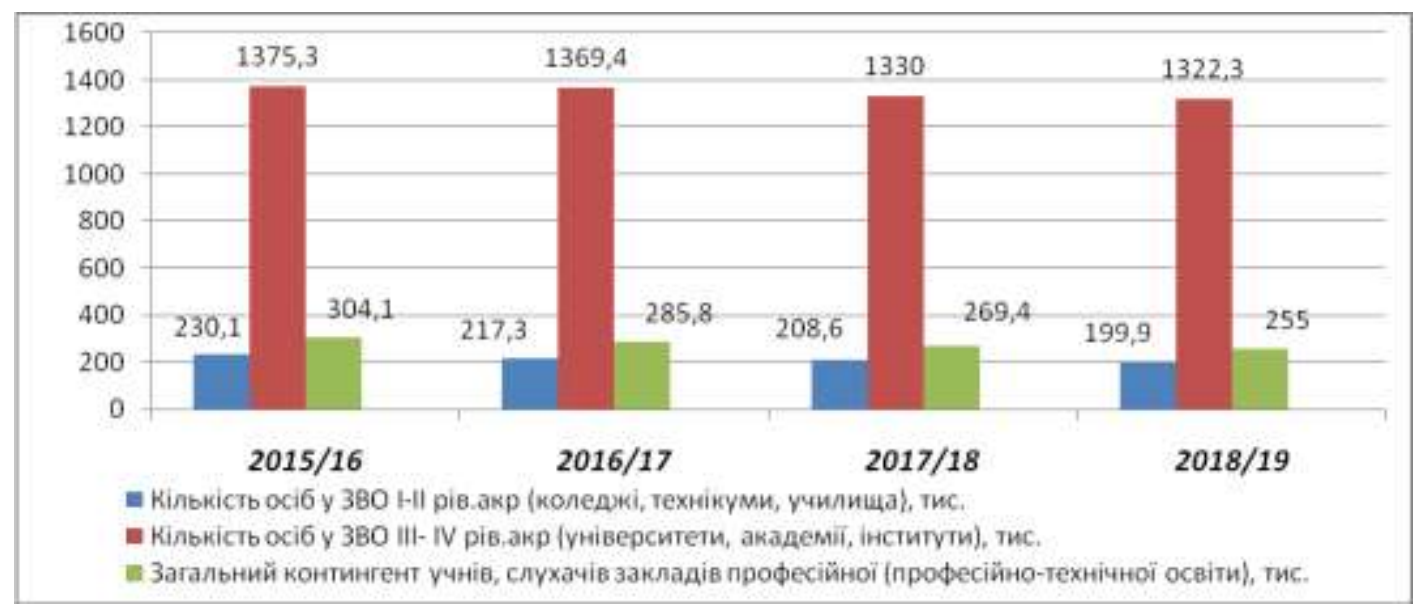

Рис. 2 
Молодь України, характеризується доволі високим рівнем освіченості та активністю до здобуття освіти. За підрахунками Міністерства освіти, 79 \% української молоді 18-26 років отримує вищу освіту (мається на увазі базова вища та університетська, всіх рівнів акредитації), що забезпечує Україні місце у світовій двадцятці за цим показником (Ukrainske pokolinnia Z: tsinnosti ta oriientyry, 2017). Україна, за останні кілька років за цим показником займає 10-12 місце. Лідерами у світі є: Південна Корея - 98,4\%, США - 94,3\%, Фінляндія - 93,7 \%, Білорусь - 91,5 \% і Австралія - 86,3 \% (2012 р.). У розрізі соціологічних даних, у 2016 р. більше половини зарахованих абітурієнтів - $51 \%$ від загального обсягу - навчалися за кошти держави порівняно $338 \%$ у 2010 p. (Ukrainske pokolinnia Z: tsinnosti ta oriientyry, 2017).

В Україні протягом 2017-2018 н. р. (згідно даних Державної служби статистики), кожна 4 молода особа (у віці від 15 до 35 років) була охоплена освітою (за всіма формами навчання). 3 них, близько $32 \%$ є учнями загальноосвітніх навчальних закладів; 10,3 \% рівнем освіченості є студентами професійно-технічних навчальних закладів; 7,8 \% - студентами закладів вищої освіти I-II рівнів акредитації; майже 50 \% - студентами закладів вищої освіти III-IV рівнів акредитації; менш ніж 1 \% - аспіранти та докторанти молодого віку (Vyshcha osvita v Ukraini: Statystychnyi zbirnyk, 2018). На 288 університетів, урозрахунку на чисельність населення України припадає в середньому 6,35 університетів на 1 млн. осіб. Для порівняння, у Великій Британії аналогічний показник становить 2,48, у Швеції - 4,95, а у Німеччині - 5,28 (Ukrainske pokolinnia Z: tsinnosti ta oriientyry, 2017).

Для більшості шкільної молоді (згідно результатів загальнонаціонального опитування «Українське покоління Z: цінності та орієнтири (2017 р.),вища освіта є ціннісним орієнтиром. Зокрема $83 \%$ респондентів вважають що спеціальні знання та досвід є цінним для них у здобутті освіти, а 76 \% вважають, що рівень освіти є важливими факторами при пошуку роботи (Ukrainske pokolinnia Z: tsinnosti ta oriientyry, 2017).

Хоча прослідковується зменшення обсягів державного замовлення у закладах вищої освіти України (зокрема, у 2018 році кількість бюджетних місць у вишах скоротилася на 9,6\% (за даними НАПН), на фоні тренду зменшення чисельності випускників як в цілому по Україні, так і за всіма освітньо-кваліфікаційними рівнями, все ж для України є характерним високий рівень тяжіння молоді до вищої освіти. Так в оцінці того, «що для молоді є найважливішим зараз?», згідно результатів всеукраїнського соціологічного дослідження «Цінності молоді - 2016», позиція «Здобуття вищої освіти» для молоді стоїть на 13 місці (15,9 \%) серед переліку 21 важливих життєвих питань. В оцінці своїх можливостей отримати хорошу освіту, спеціальність, професійну підготовку, які визнавалися б у всьому світі, 29,2\% «достатньо високо» 
оцінили, 42,2 \% - «середньо», 21,4 \% - «достатньо низько». 7,3 \% - не мали такого бажання (Tsinnosti molodi - 2016..., 2016).

У 2016 році за статистикою вступу до ВНЗ потрапили 80\% випускників шкіл порівняно з 50\% у 2000 році (Vyshcha osvita v Ukraini: hromadska dumka studentiv..., 2015). За міжнародним показником рівня залученості до вищої освіти (Gross Enrolment Ratio - відсоток осіб, що одержують вищу освіту, незалежно від їхнього віку, від загальної кількості осіб, які мають типовий для одержання вищої освіти вік) Україна посідає одне з чинних місць серед країн Центральної та Східної Європи (Oksamytna, 2010).

До певних позитивних змін призвело і запровадження 32008 року системи Зовнішнього незалежного оцінювання (ЗНО) як основного критерію вступу до вищого навчального закладу. Суттєво змінилось і сприйняття доступності освіти. Згідно з результатами дослідження «Молодь України 2015», $76 \%$ студентів підтримують систему вступу до ВНЗ за результатами ЗНО (Molod Ukrainy - 2015). Згідно опитувань Громадської мережі «Опора» та GFK, у 2016 році, 90 \% учасників тестування мали довіру до системи 3НО (Ukrainske pokolinnia Z: tsinnosti ta oriientyry, 2017).

Обираючи місце для навчання, молодь найчастіше орієнтується, i це цілком закономірно, на престижність закладу вищої освіти, його територіальне знаходження та наявність бюджетних місць, співставляючи власні інтереси та можливості. Постійний характер мають й показники розподілу студентів за регіонами отримання освіти. Стабільно, найбільш активними освітніми центрами, за статистичними даними в освітній сфері, $\epsilon$ м. Київ $(24,1 \%$ від загальної чисельності студентів), Харківська $(11,1 \%)$, Львівська (8 \%), Дніпропетровська (7,35 \%) та Одеська (6,9 \%) області (Vyshcha osvita v Ukraini: Statystychnyi zbirnyk, 2018).

За даними дослідницького центру CEDOS (2018р.), понад $95 \%$ зарахованих на бюджет, що походять з Києва та Харківської області, обрали заклади своєї області. Далі йдуть Львівська та Одеська області, де цей показник перевищує 83 \%, а за ними - Чернівецька область із показником $77 \%$. Інші області розташувались в діапазоні від $31 \%$ у Рівненській до $62 \%$ у Закарпатській областях (Analitychnyi tsentr CEDOS, 2017).

Сучасне молоде покоління обирає специфічні, характерні тільки для нього пріоритети професійного розвитку, які не досить гармонійно співпадають з реаліями. Практично молоді люди не обирають класичних професій у промисловості, будівництві, сільському господарстві, сфері культури. Тому існує дисбаланс між професійними намірами молоді і попитом на ринку праці. Згідно результатів різних соціологічних досліджень («Цінності української молоді - 2017», «Українське покоління Z: цінності та орієнтири (2017)), загалом, найбільш привабливими професіями для молоді віком 
14-34 роки є: бізнесмен/підприємець, юрист, спеціаліст 3 програмного забезпечення і комп'ютерної техніки, лікар, державний службовець та інші. До того ж ці професії, на думку молодих людей, забезпечують успіх особистості у майбутньому ((Ukrainske pokolinnia Z: tsinnosti ta oriientyry, 2017).

Серед основних факторів, що впливають на розвиток професійної спрямованості та самовизначення, $\epsilon$ цінність професії та їі престиж, котрі виражаються головними у прийнятній оплаті та стабільності, розкритті і застосуванні своїх здібностей, результатах роботи. За даними дослідження «Українське покоління Z: цінності та орієнтири (2017) ((Ukrainske pokolinnia Z: tsinnosti ta oriientyry, 2017), перше місце посідає - дохід (він є вкрай важливим для 96 \% молоді), друге місце займає - стабільність (94 \%), третє та четверте можливість досягти певних цілей та кар'єрні можливості (по 84 \%). Пріоритетність матеріальних привілеїв (згідно результатів дослідження «Молодь України - 2018» та дослідження професійних намірів учнів 8-х класів (2018 р.) коливається в межах від 26,8 \% до 29 \%. Можливість самореалізації та відповідність особистим інтересам, вподобанням - від 44\% до 49,4\% (Molod Ukrainy - 2018: Rezultaty..., 2018; Sotsiolohichne doslidzhennia profesiinykh namiriv uchniv 8-kh klasiv, 2018).

Не дивлячись на постійну роботу державних та публічних органів з інформування щодо актуальних потреб та професій на ринку праці, молодь все одно обирає ті, які є, на їхню думку, найбільш престижними, а бо ті, які дають можливість навчання за рахунок бюджетних коштів. На затребуваність професії на ринку праці, «традиційно» мало хто звертає уваги. Хоча половина студентів здобувають вищу освіту саме для кращого працевлаштування. Про знання та навички (за даними аналітичного центру CEDOS), які стануть у пригоді під час роботи, а також про можливість обійняти перспективну посаду свідчать відповідно $50 \%$ та $51 \%$ респондентів (Analitychnyi tsentr CEDOS, 2017).

У 2017 році (згідно результатів соціологічного опитування «Молодь України - 2017», найпривабливішими професійними видами діяльності для молоді, що мають інструментальну цінність, на разі були: «бізнесмен/ підприємець» (45,2%), «юрист» $(36,1 \%)$ і «спеціаліст IT» $(31,2$ \%), «медик» (29,9\%), «держслужбовець» $(20,5$ \%), «банківський працівник» $(16,6 \%)$, «працівник творчої професії» (16,3%) (Molod Ukrainy - 2017).

У 2018 році (згідно результатів соціологічного опитування «Молодь України - 2018»), найпрестижнішими для вибору кар'єри, на думку самої молоді, є такі сфери, як: IT-сфера (55,7\%), юридична $(38,7 \%)$ і банківська $(33,5 \%)$ сфери (рейтинг найпрестижніших сфер для вибору кар'єри за статтю та типом поселення структурно не розрізняється) (Molod Ukrainy - 2018: Zvit, 
2018). Дизайн-структура професійних преференцій молоді за останні роки суттєво не змінюється.

У 2017-2018 н. (за даними освітньої статистики), серед бакалаврів, найбільш популярними були такі галузі знань, як: управління та адміністрування (14 \% студентів), освіта/педагогіка $(12,1 \%)$, право $(10,1 \%)$, інформаційні технології (7,8 \%), соціальні та поведінкові науки (6,7\%). Студенти-магістри переважають у навчанні за напрямами підготовки: управління та адміністрування (19,5\%), освіта/педагогіка $(11,1 \%)$, охорона здоров'я (9,3 \%), право (8,3\%), соціальні та поведінкові науки $(7,4 \%)$, інформаційні технології (4,9\%) (Vyshcha osvita v Ukraini: Statystychnyi zbirnyk, 2018). Рейтинг популярності за даними вступної компанії 2019 року практично не змінився (Osvita UA).

Однак структура затребуваних професій та спеціальностей суттєво відрізняється від професійних преференцій університетської молоді. Підтверджує цей факт наявність великої розбіжності між кількістю випускників та стійким попитом на фахівців окремих професій. Особливо виразною є картина серед педагогів (освітян) та лікарів. У разі можливостей обирати для вивчення соціально-гуманітарні дисципліни (згідно результатів загальнонаціонального опитування студентів від фонду «Демократичні ініціативи» 2015 р,), більшість студентів (причому усіх профілів навчання) обрали б іноземну мову (63\%), психологію (35\%), українську мову (28\%) та історію України (27 \%) (Vyshcha osvita v Ukraini: hromadska dumka studentiv, 2015).

Основним мотивом обрання свого навчального закладу студенти назвали власне бажання, інтерес (48 \%), значно менше (18 \%) орієнтувалися на престиж професії, можливості подальшого працевлаштування. Водночас, згідно того ж опитування, 46 \% студентів певні, що у майбутньому працюватимуть за отриманою спеціальністю (Vyshcha osvita v Ukraini: hromadska dumka studentiv, 2015). Найбільше «вірні» своєму вибору професії студенти-митці, серед яких $57 \%$ впевнено збираються працювати за спеціальністю, не коливаючись від свого вибору. А найменше налаштовані на роботу за обраною професією студенти технічного профілю - 34 \% (Vyshcha osvita v Ukraini: hromadska dumka studentiv, 2015).

Дещо простіша ситуація у сфері професійно-технічної освіти. Освітньопрофесійний етос даної категорії молодих людей (як чітко визначений набір ідеальних культурних взірців), виступає адаптивним ресурсом у системі професійної зайнятості. У 2018-2019 н. р. учні та слухачі закладів ПТО здобували освіту за 340 робітничими професіями та 59 спеціальностями освітньо-кваліфікаційного рівня «молодший спеціаліст». Найбільш «популярними» серед вступників закладів ПТО були такі професії: 1. Водій 
автотранспортних засобів; 2. Кухар; 3. Тракторист-машиніст с/г (лісогосподарського) виробництва; 4. Слюсар з ремонту колісних транспортних засобів; 5. Електрогазозварник; 6. Кондитер; $\quad$ 7. Перукар (перукармодельєр); 8. Слюсар з ремонту с/г машин та устаткування; 9. Електрозварник ручного зварювання; 10.Кравець; 11. Електромонтер 3 ремонту та обслуговування електроустаткування; 12. Муляр; 13. Манікюрник (Osvitnia reforma: rezultaty ta perspektyvy, 2019).

Сучасна українська молодь відчуває певний рівень незадоволеності освітою, яку вона отримує в межах навчального закладу, однак, близько 2/3 молоді задоволені своїм рівнем освіти. Це підтверджують результати досліджень останніх чотирьох років. Так, за опитуваннями «Молодь України 2015» (Molod Ukrainy -2015, 2015), 67 \% представників української молоді цілком або скоріше задоволені своєю освітою. За опитуваннями 2016 року (Tsinnosti molodi - 2016: Rezultaty..., 2016; Molod Ukrainy - 2017, 2017) -66,5 \% молоді задоволені своєю освітою. Дослідження 2017 року (Molod Ukrainy 2018: Zvit, 2018) вказують, відповідно на 65,3\% таких. Дослідження проведені в рамках проекту «Українське покоління Z: цінності та орієнтири» (2017р.) показують, що 72 \% задоволені рівнем освіти, однак, тільки третина вважає, що українська освіта відповідає потребам сучасного ринку праці (Ukrainske pokolinnia Z: tsinnosti ta orientyry, 2017). За статтю, в цих оцінках молоді суттєвих відмінностей не виявлено (різниця близько у 3-5\%). Однак міська молодь (67,5 \%) більш задоволена своїм рівнем освіти, ніж сільська (за різними дослідженнями різниця становить близько 5-8 \%), що вказує на те, що рівень освіти міської молоді є вищим за рівень освіти сільської молоді.

Оцінка своїх реальних можливостей, що отримує молодь разом з набутою освітою, вказує і на достатній рівень задоволеності отриманими компетенціями задля їх реалізації у трудовій сфері: молоді люди вважають (результати соціологічного дослідження «Молодь України - 2017»), що отримана ними освіта дає можливості розвиватися $(54,5$ \%), однак, 31,2 \% так не вважають, і вказують на зворотнє (Molod Ukrainy - 2017, 2017).

Більше ніж половина опитаних представників молоді (53\%) хотіла б мати високий рівень освітньої підготовки. Закономірно, що найбільше таких серед тих, хто навчається в середніх навчальних закладах - $71 \%$. Серед основних мотивів прагнення до підвищення освіти (згідно опитування «Молодь України - 2015), є: особиста потреба у підвищенні рівня освіти - 53 \%, можливість влаштуватися на більш престижну роботу - 53 \%, можливість більш високого заробітку - 50 \% (Molod Ukrainy -2015, 2015).

Майже половина опитаних респондентів вважає, що навчання дозволяє отримати професію та зробити кар'єру (47,3%). 21,9\% молоді вважає, що освіта дає можливість бути освіченим та 15,3 \% респондентів вважають, що навчання 
допомагає підготуватися до самостійного життя. 8,3 \% молоді пов'язують із навчанням утвердження в житті. Тільки 3,5\% опитаної молоді вважають навчання марно витраченим часом (Molod Ukrainy - 2017, 2017).

Щодо шансів знайти після закінчення ВНЗ добру роботу, переважає точка зору, що для цього потрібно мати добру освіту, високий рівень знань (45\%), і менше покладаються на знайомства та зв'язки (36\%). Варто зауважити, що ще у 2011 році, ситуація була зворотною: студенти більше покладалися на зв'язки (43\%), ніж на освіту (38 \%) (Vyshcha osvita v Ukraini: hromadska dumka studentiv, 2015).

$€$ доволі полемічним питання вагомості основних причин незадоволення молоді якістю своєї освіти. Однак, зважаючи на думку фахівців, варто звернути увагу на: суб'єктивність оцінки; невідповідність преференцій молоді щодо обрання професій у відповідності до потреб ринку праці; недосконалість механізму мотивування освіти та не завжди належний рівень надання якості освітніх послуг; важкий механізм працевлаштування молоді після закінчення навчального закладу і відсутність необхідного досвіду до поточних потреб. Всі вони системно взаємопов'язані між собою. Мінливість внутрішніх (особистісних) преференцій молодих людей щодо професійного самовизначення та зовнішніх життєвих (суспільних) умов створюють систему протиріч та соціальну напруженість. Молодь пробує «секуляризуватися» від класичної вищої освіти на користь вузькоспеціалізованих курсів або самозайнятості. Це, так би мовити, пошук «освіти для себе». У багатьох випадках потреби у вищій освіті дійсно немає в силу того, що не вистачає не керівників і менеджерів, а саме висококваліфікованих робітників. В той же час дуже багато молодих людей використовує час студентства як можливість пожити з батьками, як певний спосіб не бути самостійним і не піклуватися про себе, автоматично продовживши юність(NV).

Переважна більшість молодих людей після отримання професійної та вищої освіти не працюють за фахом з причин невідповідності вимогам професії або невідповідності професій, запропонованих ринком праці, можливостям і потребам людини. Певною мірою таке становище $є$ наслідком недостатнього інформування щодо вимог професій. Стабільним, протягом кількох років, залишається питома вага учнів, слухачів ПТО, що працевлаштувалися за отриманою професією. На початку 2019 року цей рівень, за даними освітньої статистики, становив 82,76 \% (109,58 тис. осіб), на початку 2018 року - 81,7 \% від загального випуску (114,8 тис. осіб), 7,2 \% (10,2 тис. осіб) продовжували навчання у закладах вищої освіти, а 60 \% від загального випуску (83,6 тис. осіб) отримали дві і більше професій (Osvita v Ukraini: bazovi indykatory, 2018; Osvitnia reforma: rezultaty ta perspektyvy, 2019). Однак, згідно дослідження 2018 року («Молодь України - 2018»), 48,1% опитаної молоді, яка працевлаштована, 
працює не за фахом чи спеціальністю, отриманою в професійно-технічному або вищому навчальному закладі (Molod Ukrainy - 2018: Zvit, 2018).

Проте неоднозначна ситуація із працевлаштуванням нещодавніх випускників вузів. Офіційна статистика не дає чіткого уявлення про відсоток випускників ВНЗ, які не можуть знайти роботу після здобуття відповідного освітнього рівня. Однак $\epsilon$ дані освітньої статистики про те, що частка не працевлаштованих випускників 30Н3 та 3 ВО у 2015 р становила близько 16,4 \%, а у 2016 р. - 15,6 \% (Derzhavna sluzhba statystyky Ukrainy).

Дослідження життєвих планів молоді, їхніх уподобань і пріоритетів $€$ одним із засобів покращення наукової організації профорієнтаційної роботи, підвищення їі ефективності. Відсутність вакансій за фахом (36,7\%) та незадовільна матеріальна винагорода $(31,4 \%) \in$ головними чинники (про які ми говорили), котрі пояснюють чому молодь не працює за здобутим фахом. Тому не дивно, що 28,5\% молоді хотіли б змінити професію, яку вони мають (опитування 2017 та 2018 рр.) (Molod Ukrainy - 2018: Zvit, 2018; Molod Ukrainy - 2017, 2017). Серед міської молоді (30,4\%) більше тих, хто хотів би змінити свою професію, ніж серед сільської молоді (24,3%).

Майже половина опитаних (49,4\%) зазначила, що обрала або планує обрати свою останню спеціальність або нинішню професію, тому що вона відповідає їхнім інтересам, захопленням, здібностям. 26,8 \% вказали, що обрали або планують обрати нинішню професію, тому що вона гарантує заробіток, гідну матеріальну винагороду.

Питання подальшого освітньо-професійного самовдосконалення молоді також виступає ознакою її соціальної активності. За результатами дослідження «Молодь України - 2018, дві третини (66,1\%) опитуваної молоді вказали, що упродовж останніх 3-х років відвідували курси, семінари, тренінги. 3,5 \% опитаної молоді одночасно навчаються або навчалися за кількома напрямами в одному навчальному закладі, 1,5 \% - одночасно навчаються або навчалися у кількох навчальних закладах в Україні, стільки ж (1,6\%) - навчаються або навчалися за програмою паралельного навчання для отримання подвійного диплому (вітчизняного та іноземного навчальних закладів), а 29,0\% респондентів зазначили, що вони планують паралельно здобувати іншу освіту (Molod Ukrainy - 2018: Zvit, 2018). 31,2 \% опитаної молоді працюють або працювали під час навчання. Переважно це у приватних компаніях 49,5 \%, дещо менше - в державному секторі (17,2\%). Також ними було зазначено, що проходили стажування / учнівство в приватних компаніях (16,0\%) i державному секторі (10,5 \%) (Molod Ukrainy - 2018: Zvit, 2018).

У професійно-технічній освітній сфері за даними моніторингових досліджень ІПТО НАПН України (2016-2018), переважна більшість учнів (57,3 \%) після закінченню навчання планує працювати за набутою професією, 
20,3 \% планує працювати за іншою професією, а 22,4 \% планує продовжити навчання у закладах вищої освіти (Informatsiino-analitychni materialy NAPN...).

На основі опитування учнів закладів професійної освіти, з'ясовано, що найбільш вагомими чинниками вибору професії $є$ власне бажання та поради батьків, друзів та родичів. Профорієнтаційна робота органів служби зайнятості посідає останнє місце. Аналіз мотивації учнів щодо вибору закладу освіти свідчить про те, що професійні преференції тут $\epsilon$ маловпливовими: 34,8 \% учнів не мають чіткої впевненості в тому, що обрана професія відповідає їхнім матеріальним і духовним потребам. А 42,5 \% учнів закладів П(ПТ)0 не збираються працювати за обраною професією (Informatsiino-analitychni materialy NAPN...).

Найбільшими труднощами, з якими зустрічаються студенти у процесі їх підготовки до майбутньої професійної кар'єри, є: особистісні, які пов'язані із діяльністю та поведінкою самих студентів, та освітні, які стосуються діяльності вищих навчальних закладів. До особистісних належать: негативний вплив особистісних якостей студентів, відсутність самоорганізації, фінансові проблеми, нерозуміння матеріалу, мотиваційна відсутність. Освітню групу труднощів, за оцінкою учнів та студентів, складають недосконалість та неналежна якість освітньо-професійних послуг.

Найбільш серйозними проблемами вищої освіти, які потребують першочергового розв'язання, більшість студентів вважає невизнання дипломів більшості вітчизняних ВНЗ у світі (51 \%), невідповідність викладання вимогам ринку (41\%), корумпованість викладацького складу ВНЗ (39\%), низький рівень якості освіти в українських ВНЗ порівняно зі світовим рівнем (32 \%). Водночас студенти не вбачають серйозної проблеми у низькому професійному рівні викладачів (9\%) та у відсутності студентського самоуправління (8 \%) (Vyshcha osvita v Ukraini: hromadska dumka studentiv, 2015).

Серед проблем, що спричинюють незадоволеність освітою (згідно результатів національних опитувань студентської молоді) - корупція, відсутність належної практики та інновацій у навчанні, а також перевантаженість навчальної програми зайвими предметами, які ніяк не пов'язані зі спеціальністю (Ukrainske pokolinnia Z: tsinnosti ta oriientyry, 2017). 3 випадками корупції у ВНЗ безпосередньо стикалися 34 \% студентів, ще $26 \%$ чули про це від інших. Зовсім не стикалися з явищами корупції у своєму ВН3 $40 \%$ опитаних студентів (Vyshcha osvita v Ukraini: hromadska dumka studentiv, 2015).

Окрім корупції, проблемою української системи освіти є низька якість освітніх послуг. Зокрема, невідповідність освітніх послуг чинним стандартам (62\%), брак матеріально-технічного, фінансового та іншого забезпечення ВНЗ (60 \%), неможливість або формальне проходження практики (52%) (Ukrainske 
pokolinnia Z: tsinnosti ta oriientyry, 2017). Загалом більшість студентів оцінили якість вищої освіти в Україні нижче середнього - у 2,8 бала за 5 бальною шкалою; ця оцінка істотно нижча за ту, що ніж була у 2011 році (3,5 бала). Щоправда, якість освіти у своєму ВНЗ студенти оцінили вище - у 3,2 бала, хоча також дещо нижче, ніж було у 2011 році (3,6 бала), як зазначають результати загальнонаціонального опитування студентів. від фонду «Демократичні ініціативи» 2015 року (Vyshcha osvita v Ukraini: hromadska dumka studentiv, 2015).

Основною проблемою української системи шкільної освіти $є$ і нерівність між селом і містом (Samokhin), тобто нерівні умови підготовки учнів до вступу у ВН3. Результати 3 НО свідчать, що учні сільських шкіл мають гірші оцінки, ніж учні з міст, а найкращі результати показують учні столичних шкіл (Samokhin). За результатами відповідних досліджень, 29 \% учасників ЗНО вважають, що шкільних знань недостатньо для проходження тестування, а 7 \% вважають, що цих знань недостатньо навіть для отримання мінімальних балів, тому батьки часто змушені наймати репетиторів за власний кошт. А отже, якість шкільної освіти в Україні напряму залежить від соціально-економічного середовища родини (Molod Ukrainy -2015, 2015).

Питання освітньої еміграції молоді для України заслуговує не абиякої уваги, однак, не стільки з проблем освіти в Україні, скільки з соціальних. Сьогодні спеціальні дослідження (зокрема дослідження CEDOS) показують, що молодь, яка поїхала вчитись за кордон, більше не задоволена умовами життя в Україні загалом, ніж станом вищої освіти зокрема. Вона розглядає вищу освіту в іншій країні як місток до подальшого життя після випуску в кращих умовах поза межами України. Однак, далеко не все українське студентство залишається за кордоном, навіть якщо такими були їхні початкові плани (Analitychnyi tsentr CEDOS).

У 2016-2017 н. р. за розрахунками аналітичного центру CEDOS, кількість молодих людей з українським громадянством, які навчались узакордонних університетах було 77,42 тис. осіб, і становила близько $8 \%$ від загальної кількості тих, хто вчиться на денних (близько 900 тис.) програмах вищої освіти. Якщо взяти до уваги всіх студентів ВНЗ України того періоду (1369,4 тис.), то це становить близько 5,6 \%. Найчастіше їдуть до Польщі, Росії, Німеччини, Канади, Чехії, Італії, США, Іспанії, Австрії, Франції, Словаччини. Протягом останніх дев'яти років кількість зросла більш ніж утричі - з 24,1 тис. (2011) до 77, 42 тис. осіб.(2017/18) Причому 2/3 цього приросту склали саме українці, які навчаються в польських університетах. Українське студентство $є$ стратегічно важливим ресурсом, перед для Польщі, де вони складають $55 \%$ від усього іноземного студентства. 3 огляду на те, що більшість з них платить зісвоєї кишені і за навчання, і за проживання, це важливі інвестиції для Польщі, 
які компенсують демографічний спад та виїзд польської молоді до закладів вищої освіти в інших країнах ЄC (Analitychnyi tsentr CEDOS).

Водночас у 2015 році більшість студентів (69\%, у 2011 було $55 \%$ ) хотіли б навчатися за кордоном (найбільше - ті, що навчаються за технічним профілем, майже 80 \%). Основна перешкода навчанню за кордоном - нестача коштів (на це вказали $71 \%$ студентів, у 2011 році було $52 \%$ ) та недостатнє знання іноземних мов (37,5\%, у 2011 році - 34\%) (Vyshcha osvita v Ukraini: hromadska dumka studentiv, 2015). Стримати відтік молоді за кордон на навчання (на думку експертів CEDOS) (Analitychnyi tsentr CEDOS), може допомогти певним чином - підвищення якості вищої освіти в Україні, зниження цін на контрактне навчання в українських університетах, у комплексі з іншими змінами, які мають підвищити рівень життя в Україні. Однак, збільшення кількості бюджетних місць в українських університетах цього ефекту не дасть.

\section{Висновки}

Відсутність певних професійних перспектив, з посиленням конкуренції та за умов безробіття, для молодого покоління висуваються жорсткі вимоги щодо обов'язкової наявності вищої освіти. У розвитку ж творчої активності молодої людини відіграють найбільш важливу роль - вибір життєвих цілей. I, як бачимо, домінантом мотивів здобуття освіти у нинішніх студентів найчастіше є отримання шансу на благополучне майбутнє, що виявляє в собі також і «культу диплома». Це $\epsilon$ характерним для слабкої раціональної установки отримання освіти. 3 позиції початкового опанування професії та подальшого кар'єрного зростання, молода людина, у більшості випадків, сама, свідомо, з раціональною установкою звертатиметься до освітніх послуг. Тому, процес взаємопроникливості життєвих цілей, професійних перспектив молодої людини, з одного боку, та трансформуючої освітньо-професійної системи з іншого, перманентно наштовхуватиметься на суттєві «перешкоди» системного характеру. Зокрема, це стосується і низького рівня темпів суспільно-економічного розвитку України.

3 огляду на те, що професійна освіта виконує визначене соціальне замовлення суспільства, вона дедалі більше повинна розглядатися як головний етап підготовки та адаптації молодих людей до реалій інформаційного суспільства, вбачаючи у підготовці спеціаліста творчий процес формування особистості з вмінням самостійно розв'язувати суспільно значимі проблеми, чого зараз цього не спостерігається.

\section{References:}

1. Analitychnyi tsentr CEDOS. Ukrainske studentstvo za kordonom: dani do 2017/18 navchalnoho roku [CEDOS think tank. Ukrainian students abroad: data for 
the 2017/18 academic year]. Available at: https://cedos.org.ua/uk/articles/ukrainske-studentstvo-za-kordonom-dani-do201718-navchalnoho-roku.

2. Derzhavna sluzhba statystyky Ukrainy [State Statistics Service of Ukraine: website]. Available at: http://ukrstat.gov.ua.

3. Derzhavna sluzhba statystyky: zaklady vyshchoi osvity [State Statistics Service: higher education institutions]. (2005). Available at: http://www.ukrstat.gov.ua/operativ/operativ2005/osv_rik/osv_u/vuz_u.html.

4. Informatsiino-analitychni materialy NAPN Ukrainy do shchorichnoi Derzhavnoi dopovidi pro stanovyshche molodi v Ukraini (za pidsumkamy 2018 r.) [Information and analytical materials of the National Academy of Pedagogical Sciences of Ukraine to the Annual State Report on the Situation of Youth in Ukraine (asof 2018)].

5. Kohut, I., Samokhin, I., Stadnyi, Ye., Kudelia, M., Zherobkina, T. ed. (2016). Sotsialno-ekonomichnyi portret studentiv: rezultaty opytuvannia [Socio-economic portrait of students: results of the survey]. Available at: https://cedos.org.ua/uk/articles/sotsialno-ekonomichnyi-portret-studentivrezultaty-opytuvannia.

6. Molod Ukrainy - 2015 [Youth of Ukraine-2015]. (2015). Kyiv: Ministry of Youth and Sports of Ukraine; HFK Yukrein.

7. Molod Ukrainy - 2017: rezultaty sotsiolohichnoho doslidzhennia [Youth of Ukraine - 2017: results of a sociological survey]. Kyiv: “Omega" Center for Independent Sociological Research.

8. Molod Ukrainy - 2018: Rezultaty reprezentatyvnoho sotsiolohichnoho doslidzhennia [Youth of Ukraine - 2018. Results of a representative sociological survey]. (2018). Kyiv: Redaktsiia informatsiinoho biuletenia "Ofitsiinyi visnyk Prezydenta Ukrainy".

9. Molod Ukrainy - 2018: Zvit. Rezultaty sotsiolohichnoho doslidzhennia ["Youth of Ukraine 2018» Report. Results of sociological research]. (2018). Kyiv: Ministry of Science and Educations of Ukraine; TOV "Persha reitynhova systema".

10. NV [NV: Recourse]. Available at: https://nv.ua/ukr/opinion/navishchovam-vishcha-osvita-687330.html.

11. Oksamytna, S. (Eds.). (2010). Molod Ukrainy: vid osvity do pratsi [Youth of Ukraine: from education to work]. Kyiv.: VPTsNaUKMA.

12. Osvita UA [Osvita UA: Recourse]. Available at: https://osvita.ua/consultations/bachelor/65128/.

13. Osvita v Ukraini: bazovi indykatory. Informatsiino-statystychnyi biuleten [Education in Ukraine: basic indicators. Information bulletin]. (2018). Kyiv: State Scientific Institution "Instytut osvitnoi analityky", Ministry of Science of Ukraine. 
14. Osvitnia reforma: rezultaty ta perspektyvy: informatsiino-analitychnyi zbirnyk. Instytutosvitnoianalityky [Educational reform: results and perspectives: an information and analytical compendium. Institute o fEducational Analytics]. (2019). Kyiv: Ministry of Science and Education of Ukraine.

15. Samokhin, I. Demohrafichna kryza ta nerivnist v ukrainskii shkilnii systemi: analiz novoi bazy danykh "Shkilna karta Ukrainy" [Democratic crisis and Inequality in the Ukrainian School System: An Analysis of the New School Map of Ukraine Database]. Available at: https://cedos.org.ua/edustat/graph.

16. Sotsiolohichne doslidzhennia profesiinykh namiriv uchniv 8-kh klasiv [Sociological study of the professional intentions of students of 8th grade]. (2018). Available at: https://chk.dcz.gov.ua/novyna/sociologichne-doslidzhennyaprofesiynyh-namiriv-uchniv-8-h-klasiv.

17. Tsinnosti molodi - 2016: Rezultaty vseukrainskoho sotsiolohichnoho doslidzhennia [Results of the All-Ukrainian Sociological Survey "Youth Values 2016"]. (2016). Kyiv. Available at: https://www.prostir.ua/?library=tsinnostiukrajinskoji-molodi.

18. Tsinnosti ukrainskoi molodi - 2017 [Values of Ukrainian youth - 2017]. Kyiv: "Omega" Center for Independent Sociological Research. Available at: http://neweurope.org.ua/wp-content/uploads/2017/11/Ukr_ Generation_ukr_inet1.pdf.

19. Ukrainske pokolinnia Z: tsinnosti ta oriientyry. Rezultaty zahalnonatsionalnoho opytuvannia [Ukrainian Generation Z: values and benchmarks. Results of a nationwide survey]. (2017). Available at:http://neweurope.org.ua/wpcontent/uploads/2017/11/Ukr_Generation_ukr_inet2.pdf.

20. Vyshcha osvita $v$ Ukraini: hromadska dumka studentiv. Rezultaty Zahalnonatsionalnoho opytuvannia studentiv [Higher education in Ukraine: public opinion of students. Results of the National Student Survey]. (2015). Kyiv: Fond "Demokratychni initsiatyvy" imeni Ilka Kucheriva. Available at: https://dif.org.ua/article/vishcha-osvita-v-ukraini-gromadska-dumka-studentiv.

21. Vyshcha osvita v Ukraini: Statystychnyi zbirnyk [Higher Education Statistics in Ukraine. Statistical collection]. (2018). Available at:http://www.ukrstat.gov.ua/druk/publicat/kat_u/publosvita_u.htm.

(C) Сірий Є. В., 2020 